\title{
Cytoplasm Has No Effect on the Yield and Quality of Biomass Sorghum Hybrids
}

\author{
Leo Hoffmann Jr., , William L. Rooney \\ Department of Soil and Crop Sciences, Texas A \& M University, College Station, USA \\ Email: *leo.hoffmann@ag.tamu.edu
}

Received March 6, 2013; revised April 6, 2013; accepted May 1, 2013

Copyright (C) 2013 Leo Hoffmann Jr., William L. Rooney. This is an open access article distributed under the Creative Commons Attribution License, which permits unrestricted use, distribution, and reproduction in any medium, provided the original work is properly cited.

\begin{abstract}
The development of the biomass sorghum hybrid seed industry is contingent on the use of cytoplasmic male sterility. Within sorghum, there are several different cytoplasmic male sterility systems and it is important to determine early in development if cytoplasm will affect agronomic performance or composition characters. Thus, if there is a difference, then the best system can be deployed. The purpose of this study was to determine if cytoplasm per se influences agronomic performance of biomass sorghum using a set of iso-cytoplasmic hybrids. Three hybrid genotypes were produced in three different cytoplasms (A1, A2, and A3) for a total of nine hybrids. These hybrids were evaluated for plant height, biomass yield, and biomass composition in three Texas environments (Weslaco, College Station, and Halfway) in 2010. Across environments, significant differences existed among hybrids for both agronomic and compositional traits, but cytoplasm per se had no effect on any measured trait. Since cytoplasm did not effect on hybrid performance, any of the tested cytoplasms (A1, A2, and A3) can be deployed in hybrid biomass sorghums.
\end{abstract}

Keywords: Near Infrared Spectroscopy; Photoperiod Sensitive; Cytoplasm

\section{Introduction}

New plant breeding programs have been initiated to improve several crops specifically to produce biomass for conversion to bioenergy. One species that is now being used as a bioenergy crop is sorghum (Sorghum bicolor L. Moench). Sorghum was domesticated in Africa and is known throughout the world as a grain and forage crop. The development of biomass sorghum has been enhanced due to the presence of an established production history, breeding programs and seed production systems [1].

Regardless of the type of sorghum, commercial seed production is based on hybrids produced using cytoplasmic male sterility (CMS) systems. A CMS system is essential because sorghum is a self-pollinated crop and hybrid seed production without a sterility system is not feasible. The first CMS was discovered, characterized and described by Stephens and Holland [2]. This system, designated as A1 CMS, is still used for hybrid sorghum seed production.

In 1970, the Southern Corn Leaf Blight (Helminthosporium maydis) epidemic in corn (Zea mays L.) devas-

${ }^{*}$ Corresponding author. tated corn hybrids possessing the single " $\mathrm{T}$ " cytoplasm system and it had serious consequences for hybrid crop production [3]. To avoid this potential problem in sorghum, at least four different CMS systems in sorghum were identified and characterized and some of these were made available for deployment in sorghum breeding programs [4-10]. Further characterization of these sources utilizing mitochondrial DNA sequences identified four distinct groups with the possibility that at least three more are present [11]. Thus, there is sufficient variation for CMS in sorghum to diversify if needed.

From these sources three distinct CMS systems have been developed and used to produce hybrid grain and forage sorghum seed. In addition to the original A1 CMS, which remains the most commonly used CMS system in sorghum, Schertz [8] (1977) documented and released A2 CMS in which the cytoplasm source was derived from a non-milo parent. Miller [12] and Miller et al. [13] released the seed parents with this CMS system A2Tx 632, and A2Tx636 and A2Tx637, respectively. For restoration of fertility in A2 CMS in grain sorghum hybrids, RTx432 was released [14]. A third CMS system, A3, was introduced with the release of A3Tx398 [15]. Since that time, several groups have released seed par- 
ents with A3 CMS [16-18]. These have not been used for grain sorghum hybrids because the restoration of the A3 system is gametic [19] and the frequency of restoration alleles in sorghum populations for A3 is rare [20]. However, A3 CMS has been used for the production of forage or sweet hybrids where grain is not important or desired in the commercial product [16,21].

Because hybrid biomass sorghums are unique and distinctly different than either grain or forage sorghums [1], it is important to determine which CMS system is the most appropriate to deploy for both seed and commercial crop production. Biomass sorghum hybrids are not grown for grain production; they are photoperiod sensitive and in most production environments they will not flower prior to harvest [1]. Thus, the restoration of fertility to a hybrid is not relevant for production. Furthermore, if transgenes were introduced into biomass sorghums, the presence of male sterility in the photoperiod sensitive hybrid provides a second level of protection against potential transgene transfer to other plant species.

In addition to these considerations, the selected CMS system must not reduce the yield or agronomic adaptability of the hybrid. In grain sorghum hybrids the effect of cytoplasm on performance of grain sorghum hybrids has varied, depending on study. Maves and Atkins [22] reported a reduction in grain yield in A2 hybrids compared to A1 hybrids while Kishan and Borikar [23] reported that A2 was superior to A1 for grain size and yield. Secrist and Atkins [24] found no significant differences in grain yield between A1 and A2 hybrid, but they reported a $6 \%$ reduction in grain yield in $\mathrm{A} 3$ hybrids compared to A1 hybrids. Moran and Rooney [25], evaluating iso-cytoplasmic hybrids also reported reduced grain yield in A3 hybrids compared to both A1 and A2 hybrids. In forage sorghum, Pedersen and Toy [26] tested the effect of A1 and A3 cytoplasm in forage hybrids of sorghum $\times$ sudangrass, and they found no differences associated to cytoplasm alone for maturity, height, dry yield, total yield, crude protein and in vitro dry matter disappearance.

As with grain and forage sorghum, it is important to determine if different CMS will affect agronomic performance and biomass yield. Within this context the objective of this study was to evaluate the effect of the A1, A2 and A3 CMS systems on agronomic performance and the composition of nine iso-cytoplasmic biomass sorghum hybrids.

\section{Materials and Methods}

\subsection{Hybrid Production}

Three seed parent lines and one pollinator parent were selected to produce the hybrids used in this study. The three seed parents were Tx378, Tx623 and Tx631 and all of these lines were originally developed and released with A1 CMS [12,27]. For all three, iso-cytoplasmic versions were developed in the Texas AgriLife Research sorghum breeding program [18]. These same lines were also used by Moran and Rooney [25]. Each seed parent was hybridized using the pollinator line R07007. R07007 is a photoperiod insensitive breeding line in the Texas AgriLife Research program that when hybridized to standard seed parents (such as Tx378, Tx623 and Tx631) produces a photoperiod sensitive hybrid based on epistatic genetic interactions at specific maturity loci [28,29]. Thus a total of nine hybrids, representing three genetically distinct inbreds and three distinct CMS were included in the agronomic analyses. All hybrid seed production was completed in a crossing block in College Station in 2008.

\subsection{Field Testing}

The nine hybrids were evaluated in a randomized complete block design (RCBD) with five replications at three locations in Texas in 2010. At each location, the experimental unit was composed of two rows of 7.92 meters in length and spaced 0.762 meters totaling 6.03 square meters per plot. Plots were planted and thinned to a plant density of 160,000 plants $^{-} \mathrm{ha}^{-1}$. Trials were planted in College Station (CS) on April 7th, in Halfway (HW) on June 1st and Weslaco (WE) on August 16th. These locations represent a range of different of sorghum production regions in Texas. College Station is located in the South Central region and is a subtropical environment. Halfway is in the Texas High Plains and has dry, temperate climate. Weslaco is in the Rio Grande Valley in a semi-arid but humid tropical climate. Agronomic production practices common to each region for forage sorghum were used in these studies. At WE, one supplemental furrow irrigation was applied and at HW, plots were irrigated using a center pivot systems while the CS trial was rainfed.

In each location, plant height, stem diameter, and biomass yield were measured immediately prior to harvest. Days-to-anthesis was not recorded because all of these hybrids were photoperiod sensitive and flowering did not occur in either CS or HW. Because the WE location was grown in the fall, the hybrids were just at anthesis at harvest but all flowered within 2 days so there was little to no variation among hybrids. Plant height $(\mathrm{cm})$ was measured from the base of plants (soil level) to the growing point of the plants. Plant stem diameter (Stem dia.) was measured in $\mathrm{mm}$ at the second fully extended internode from the base of three random plants prior to harvest. Plots were then harvested in CS and WE with a John Deere Silage Harvester model 5460 with three-row silage header and weighed in a wagon equipped with the Avery Weight-Tronics, model 640 electronic. In Halfway har- 
vest was performed with a one-row New Holland model 707 forage harvester, and the plot biomass was collected and weighed in an attached bin equipped with an Avery Weight-Tronics scale system model 640 with increments of $500 \mathrm{~g}$. At CS, HW, and WE, plots were harvested on 25 Aug, 16 Sept and 12 Nov, respectively. At harvest, a fresh sample was collected from each plot. These samples were weighed and dried in an air-forced flux drier at $52^{\circ} \mathrm{C} \pm 1{ }^{\circ} \mathrm{C}$ until weight stabilization. The dry samples were then weighed and moisture content was calculated as the difference in weight between the fresh and dry sample. The dried samples were ground in a Wiley Mill (Thomas Scientifics, Inc.) until the tissue passed through a $2 \mathrm{~mm}$ mesh screen and was then stored in air-tight plastic bags.

The composition analysis was predicted by near infrared spectroscopy using a FOSS XDS near infrared spectroscopy instrument (rapid content analyzer). Spectrum data were converted into composition prediction data using a calibration curve which was developed through cooperation between the sorghum research team at Texas A \& M University sorghum quality lab and National Renewable Energy Laboratory [30]. Prediction parameters were ash, lignin, xylan (hemicellulose) and glucan (cellulose and starch).

\subsection{Statistical Analysis}

Data from each environment were analyzed independently using ANOVA in Statistics Software JMP version 9 (SAS Institute, 2010). For each location the statistical model was $Y=$ mean + replication + cytoplasm + female + cytoplasm $\times$ female + error with all effects fixed. Prior to combining the data from environments, Bartlett's test for Homogeneity of Error was run to determine if combining the data was statistically valid (Bartlett, 1937). No evidence of error heterogeneity was detected; hence the data from across environments was combined and analyzed using the statistical model $Y=$ mean + environment + replication (environment) + cytoplasm + cytoplasm $\times$ environment + female + female $\times$ environment + female $\times$ cytoplasm + female $\times$ cytoplasm $\times$ environment + error with all sources of variation considered fixed. If a source of variation was significant, then mean separation was completed using the Student's T method.

\section{Results and Discussion}

Few significant effects were detected within environments; the cytoplasm effect was significant only for dry biomass yield in CS (A3 > A2 and A1) and for ash and lignin content in HW. Effects due to female were significant for lignin and xylan concentration and fresh and dry biomass yield in WE, stem diameter in HW and xylan in CS. Differences due to female were expected as these three seed parents are diverse in pedigree, phenotype and adaptation. The paucity of significant effects within each location indicates that cytoplasm per se does not affect biomass yield or composition. The interaction term (cytoplasm $\times$ female) was not significant for any measured trait.

In the combined analysis of variance, environment was a significant source of variation for every trait measured; cytoplasm was not significant for any of the agronomic or compositional traits (Table 1). The effect of female (seed parent) was significant for fresh biomass yield, dry matter, glucan and xylan, indicating that the hybrids differed for these traits. The interactions were not significant with the following exceptions: cytoplasm $\times$ environment (ash), cytoplasm $\times$ female (glucan and dry matter content), and cytoplasm $\times$ location $\times$ female (fresh biomass yield and dry matter content) (Table 1).

The effect of environment accounted for the majority of variation detected in the test (Table 1). For example, biomass yields across location ranged from 32.0 MT $\cdot \mathrm{ha}^{-1}$ (WE) to $76 \mathrm{MT} \cdot \mathrm{ha}^{-1}$ (HW) while the range for biomass yield due to female seed parent was much less and nonexistant for cytoplasm (Table 2). The lower yields in WE were the result of the late summer planting date resulting in a crop that developed into the fall season where active growth and biomass accumulation was slowed or stopped due to cool/cold weather, short daylengths and reduced light intensity. Plants were tallest in HW and shortest in WE, again likely due to the shorter growing season and daylengths in WE. Stem diameter was larger in WE and CS than in HW (Table 2). Concentrations of ash, xylan, and glucan in HW were consistently and often significantly higher than the other two environments (Table 2). While there is not an obvious reason for this observation, because these are concentrations and other compounds that are not presented in this study (i.e., protein, soluble sugar) could be higher in CS and WE environments and this would cause a concomitant reduction in other components. This is possible as other studies have shown that protein and soluble sugar contents vary in sorghum due to genotype, maturity and environment effects [31].

Because only one pollinator parent was available for use in this study, the effect of the female (seed) parent reflects any differential performance among the hybrids in this test. Among these genotypes, ATx378/R07007 produced the highest fresh biomass yields (Table 2). Differences in composition were also detected among the hybrids, specifically for glucan and xylan concentrations (Table 2). Tx378 hybrids were higher in glucan and xylan than either Tx631 or Tx623 hybrids. Both Tx631 and Tx623 tend to have higher soluble carbohydrate levels than Tx378 (data not shown) and this is reflected in the lower glucan and xylan concentrations. Overall, there were fewer differences in hybrid performance in this 
Table 1. Summary of analysis of variance (mean squares) of combined locations of agronomic and compositional traits of three photoperiod sensitive biomass sorghum hybrids with the same male parent and three different female parents in different cytoplasm systems (A1, A2 and A3) in three locations, College Station (CS), Halfway (HW) and Weslaco (WE), in Texas, 2010.

\begin{tabular}{|c|c|c|c|c|c|c|c|c|c|c|}
\hline Source & DF & Fresh yield & Dry yield & Stem diameter & Height & Dry Matter & Ash & Lignin & Glucan & Xylan \\
\hline Rep (Environment) & 12 & 207.45 & 15.15 & 10.65 & $813.73^{*}$ & 3.93 & 0.32 & 0.59 & 3.85 & $0.70^{*}$ \\
\hline Cytoplasm & 2 & 29.78 & 5.54 & 6.31 & 375.24 & 6.54 & 0.47 & 0.22 & 0.52 & 0.07 \\
\hline Environment & 2 & $21425.20^{*}$ & $1508.51^{*}$ & $187.47^{*}$ & $59146.00^{*}$ & $484.02^{*}$ & $60.88^{*}$ & $122.12^{*}$ & $103.58^{*}$ & $76.20^{*}$ \\
\hline Female & 2 & $657.76^{*}$ & 9.91 & 28.63 & 499.37 & $67.87^{*}$ & 0.29 & 0.72 & $3.50^{*}$ & $2.90^{*}$ \\
\hline Cytoplasm $\times$ Environment & 4 & 354.96 & 22.25 & 6.00 & 635.82 & 1.96 & $0.80^{*}$ & 0.83 & 0.13 & 0.35 \\
\hline Cytoplasm $\times$ Female & 4 & 237.47 & 10.99 & 11.62 & 128.09 & $11.02^{*}$ & 0.42 & 0.53 & $3.24^{*}$ & 0.37 \\
\hline Environment $\times$ Female & 4 & 155.06 & 12.52 & 3.90 & 649.70 & 1.76 & 0.35 & 0.65 & 1.72 & 0.29 \\
\hline $\begin{array}{c}\text { Cytoplasm } \times \text { Environment } \\
\times \text { Female }\end{array}$ & 8 & $372.57^{*}$ & 13.58 & 7.96 & 451.86 & $8.16^{*}$ & 0.24 & 0.59 & 0.91 & 0.36 \\
\hline Error & 93 & 166.68 & 11.63 & 8.82 & 370.71 & 3.32 & 0.29 & 0.38 & 0.87 & 0.25 \\
\hline Mean of Response & & 53.70 & 13.70 & 20.27 & 306.89 & 25.30 & 7.88 & 14.06 & 30.75 & 16.95 \\
\hline CV\% & & 24.04 & 24.90 & 14.65 & 6.27 & 7.20 & 6.79 & 4.37 & 3.04 & 2.93 \\
\hline
\end{tabular}

*Significant at level of 0.05 of probability.

Table 2. Mean separation test for three locations College Station (CS), Halfway (HW) and Weslaco (WE) and for three biomass sorghum females and three cytoplasm types, in Texas, 2010.

\begin{tabular}{|c|c|c|c|c|c|c|c|c|c|}
\hline & Fresh Yield & Dry Yield & Stem diam. & Height & Dry Matter & Ash & Lignin & Glucan & Xylan \\
\hline & $\mathrm{Mg} \cdot \mathrm{ha}^{-1}$ & $\mathrm{Mg} \cdot \mathrm{ha}^{-1}$ & $\mathrm{~mm}$ & $\mathrm{~cm}$ & $\%$ & $\%$ & $\%$ & $\%$ & $\%$ \\
\hline \multicolumn{10}{|c|}{ Environment } \\
\hline $\mathrm{CS}$ & $53.4 \mathrm{~b}$ & $15.5 \mathrm{~b}$ & $21.0 \mathrm{a}$ & $301.4 \mathrm{~b}$ & $28.9 \mathrm{a}$ & $6.8 \mathrm{c}$ & $12.2 \mathrm{c}$ & $29.2 \mathrm{c}$ & $15.7 \mathrm{c}$ \\
\hline HW & $76.8 \mathrm{a}$ & $18.7 \mathrm{a}$ & $17.8 \mathrm{~b}$ & $348.2 \mathrm{a}$ & $24.6 \mathrm{~b}$ & $9.2 \mathrm{a}$ & $14.7 \mathrm{~b}$ & $32.3 \mathrm{a}$ & $18.3 \mathrm{a}$ \\
\hline WE & $32.0 \mathrm{c}$ & $7.3 \mathrm{c}$ & $21.9 \mathrm{a}$ & $274.5 \mathrm{c}$ & $22.4 \mathrm{c}$ & $7.8 \mathrm{~b}$ & $15.4 \mathrm{a}$ & $30.9 \mathrm{~b}$ & $17.0 \mathrm{~b}$ \\
\hline \multicolumn{10}{|c|}{ Seed Parent } \\
\hline ATx631 & $52.9 \mathrm{~b}$ & $13.3 \mathrm{~ns}$ & $21.1 \mathrm{a}$ & $305.0 \mathrm{~ns}$ & $25.1 \mathrm{~b}$ & $7.9 \mathrm{~ns}$ & $14.0 \mathrm{~ns}$ & $30.6 \mathrm{~b}$ & $17.0 \mathrm{~b}$ \\
\hline ATx378 & $58.4 \mathrm{a}$ & $14.3 \mathrm{~ns}$ & $20.1 \mathrm{ab}$ & $307.4 \mathrm{~ns}$ & $24.2 \mathrm{c}$ & $8.0 \mathrm{~ns}$ & $14.2 \mathrm{~ns}$ & $31.1 \mathrm{a}$ & $17.2 \mathrm{a}$ \\
\hline ATx623 & $51.0 \mathrm{~b}$ & $13.8 \mathrm{~ns}$ & $19.5 \mathrm{~b}$ & $311.7 \mathrm{~ns}$ & $26.6 \mathrm{a}$ & $7.9 \mathrm{~ns}$ & $14.0 \mathrm{~ns}$ & $30.7 \mathrm{~b}$ & $16.7 \mathrm{c}$ \\
\hline \multicolumn{10}{|c|}{ Cytoplasm } \\
\hline A1 & $53.2 \mathrm{~ns}$ & $13.4 \mathrm{~ns}$ & $20.6 \mathrm{~ns}$ & $305.0 \mathrm{~ns}$ & $25.0 \mathrm{~ns}$ & $7.8 \mathrm{~ns}$ & $14.1 \mathrm{~ns}$ & $30.9 \mathrm{~ns}$ & $17.0 \mathrm{~ns}$ \\
\hline A2 & $54.8 \mathrm{~ns}$ & $13.9 \mathrm{~ns}$ & $19.9 \mathrm{~ns}$ & $306.8 \mathrm{~ns}$ & $25.2 \mathrm{~ns}$ & $8.0 \mathrm{~ns}$ & $14.0 \mathrm{~ns}$ & $30.7 \mathrm{~ns}$ & $16.9 \mathrm{~ns}$ \\
\hline $\mathrm{A} 3$ & $54.3 \mathrm{~ns}$ & $14.1 \mathrm{~ns}$ & $20.2 \mathrm{~ns}$ & $311.4 \mathrm{~ns}$ & $25.7 \mathrm{~ns}$ & $7.9 \mathrm{~ns}$ & $14.2 \mathrm{~ns}$ & $30.8 \mathrm{~ns}$ & $17.0 \mathrm{~ns}$ \\
\hline
\end{tabular}

Means followed by different letters are significantly different using Student's $\mathrm{T}$ test $(\mathrm{P} \leq 0.05)$.

study than in previous cytoplasm studies in grain sorghum [22,24-26] which is not uncommon as it is often more difficult to detect differences in whole plant biomass rather than the grain, which represents a partitioned portion of the total biomass [26].

At the time of this study, R07007 was only pollinator available that would produce the type of biomass hybrid evaluated in this study. Therefore, it was not possible to assess the relative effect that a male parent might have on the performance of iso-cytoplasmic hybrids. Moran and
Rooney [25], reported a significant male $\times$ cytoplasm interaction for grain yield in iso-cytoplasmic hybrids, but this effect was much smaller than the female $\times$ cytoplasm effect. Pedersen and Toy [26] evaluated eight sudangrass pollinators with four different seed parents in both A1 and A3 cytoplasm; they reported no interactions of cytoplasm with either the male or female parent for biomass yield or plant height. Thus, based on these reports, it is very unlikely that the pollinator parent would elicit a cytoplasm effect but further studies with additional pol- 
linator parents would be required to confirm this hypothesis.

The results of this study indicate that the performance of biomass sorghum hybrids is not influenced by any of the three cytoplasm systems (A1, A2 and A3) tested. These results are slightly different from other cytoplasm studies in sorghum wherein differences in grain yield were detected between different cytoplasms [23,25]. In these studies, the A3 cytoplasm was the poorest performing cytoplasm [24,32]. All these studies considered the grain yield and not total biomass yield. Pedersen and Toy [26] did not detect differences in forage yield between A1 and A3 iso-cytoplasmic forage sorghum hybrids. In the current study, grain yield is not a factor; these hybrids did not flower or were flowering at harvest.

High biomass sorghum hybrids have a promising future as a source for feedstock for biofuel production. Given that cytoplasm per se had no effect on hybrid performance, any of the tested cytoplasms (A1, A2, and A3) can be deployed in hybrid biomass sorghums. The use of A3 cytoplasm to produce male sterile hybrids will provide breeding programs the best secondary containment mechanism to avoid any potential gene flow from future transgenic energy sorghums.

\section{REFERENCES}

[1] W. L. Rooney, J. Blumenthal, B. Bean and J. E. Mullet, "Designing Sorghum as a Dedicated Bioenergy Feedstock," Biofuels Bioproducts and Biorefining, Vol. 1, No. 2, 2007, pp. 147-157. doi:10.1002/bbb.15

[2] J. C. Stephens and R. F. Holland, "Cytoplasmic Male Sterility for Hybrid Sorghum Seed Production," Agronomy Journal, Vol. 46, No. 1, 1954, pp. 20-23. doi:10.2134/agronj1954.00021962004600010006x

[3] L. A. Tatum, "The Southern Corn Leaf Blight Epidemic," Science, Vol. 173, No. 3991, 1971, p. 39. doi:10.1126/science.173.3991.39

[4] N. G. P. Rao, "Occurence of Cytoplasmic Genetic Male Sterility in Some Indian Sorghums," Indian Journal of Genetic and Plant Breed, Vol. 22, 1962, pp. 257-259.

[5] S. H. Hussaini and P. V. Rao, "A Note on the Spontaneous Ocurrence of Cytoplasmic Male Sterility in Indian Sorghum," Sorghum News, 1964, pp. 27-28.

[6] O. J. Webster and S. P. Singh, "Breeding Behavior and Histological Structure of a Nondehiscent Anther Character in Sorghum vulgare Pers. 1," Crop Science, Vol. 4, No. 6, 1964, pp. 656-658. doi:10.2135/cropsci1964.0011183X000400060032x

[7] W. M. Ross and H. L. Hackerott, "Registration of Seven Isocytoplasmic Sorghum Germplasm Lines 1 (Reg. Nos. GP 9 to GP 15)," Crop Science, Vol. 12, No. 5, 1972, pp. 720-721.

doi:10.2135/cropsci1972.0011183X001200050083x

[8] K. F. Schertz, "Registration of A2 Tx2753 and B Tx2753 Sorghum Germplasms (Reg. No. GP 30 and 31)," Crop
Science, Vol. 17, No. 6, 1977, p. 983. doi:10.2135/cropsci1977.0011183X001700060056x

[9] K. F. Schertz and J. M. Ritchey, "Cytoplasmic-Genic Male-Sterility Systems in Sorghum," Crop Sciene, Vol. 18, No. 5, 1978, pp. 890-893. doi:10.2135/cropsci1978.0011183X001800050055x

[10] J. V. Worstell, H. J. Kidd and K. F. Schertz, "Relationships among Male-Sterility Inducing Cytoplasms of Sorghum," Crop Science, Vol. 24, No. 1, 1984, pp. 186-189. doi:10.2135/cropsci1984.0011183X002400010044x

[11] G. W. Xu, Y. X. Cui, K. F. Schertz and G, E, Hart, "Isolation of Mitochondrial DNA Sequences That Distinguish Male-Sterility-Inducing Cytoplasms in Sorghum bicolor (L.) Moench," Theoretical and Applied Genetics, Vol. 90, No. 7, 1995, pp. 1180-1187.

[12] F. R. Miller, "Registration of Seven Sorghum A- and BLine Inbreds," Crop Science, Vol. 26, No. 1, 1986, pp. 216-217. doi:10.2135/cropsci1986.0011183X002600010084x

[13] F. R. Miller, T. F. Dusek and K. L. Prihoda, "Registration of A2/B2Tx636 and A2/B2Tx637," Crop Science, Vol. 32, No. 2, 1992, pp. 511-512. doi:10.2135/cropsci1992.0011183X003200020068x

[14] F. R. Miller, "Registration of RTx432 Sorghum," Crop Science, Vol. 24, No. 2, 1984, p. 392. doi:10.2135/cropsci1984.0011183X002400020066x

[15] K. F. Schertz, "Registration of A3Tx398," Crop Science, Vol. 24, No. 4, 1984, p. 833. doi:10.2135/cropsci1984.0011183X002400040067x

[16] J. F. Pedersen and J. J. Toy, "Registration of 29 Forage Sorghum Genetic Stocks in A3 Cytoplasm," Crop Science, Vol. 37, No. 4, 1997, pp. 1408-1409. doi:10.2135/cropsci1997.0011183X003700040096x

[17] J. F. Pedersen, J. J. Toy and B. E. Johnson, "Registration of 43 Sorghum Genetic Stocks in A2, A3, and A4 Cytoplasm," Crop Science, Vol. 37 No. 4, 1997, pp. 14121414.

doi:10.2135/cropsci1997.0011183X003700040102x

[18] F. R. Miller, J. A. Dahlberg and P. W. Morgan, "Registration of A3/B3 Cytoplasmic-Genetic Male-Sterile Sorghum Maturity and Height Parental Lines," Crop Science, Vol. 39, No. 1, 1999, pp. 306-307. doi:10.2135/cropsci1999.0011183X003900010081x

[19] H. V. Tang and D. R. Pring, "Conversion of Fertility Restoration of the Sorghum IS1112C (A3) Male-Sterile Cytoplasm from Two Genes to One Gene Joint contribution of the USDA-ARS and the University of Florida Agric. Exp. Stn. Published as Journal Series No. R-09082," Crop Science, Vol. 43, No. 5, 2003, pp. 1747-1753. doi:10.2135/cropsci2003.1747

[20] H. V. Tang, J. F. Pedersen, C. D. Chase and D. R. Pring, "Fertility Restoration of the Sorghum A3 Male-Sterile Cytoplasm through a Sporophytic Mechanism Derived from Sudangrass All Rights Reserved," Crop Science, Vol. 47, No. 3, 2007, pp. 943-950. doi:10.2135/cropsci2006.08.0542

[21] T. W. Pfeiffer, M. J. Bitzer, J. J. Toy and J. F. Pedersen, "Heterosis in Sweet Sorghum and Selection of a New 
Sweet Sorghum Hybrid for Use in Syrup Production in Appalachia All Rights Reserved," Crop Science, Vol. 50, No. 5, 2010, pp. 1788-1794. doi:10.2135/cropsci2009.09.0475

[22] A. J. Maves and R. E. Atkins, "Agronomic Performance of Sorghum Hybrids Produced by Using Different MaleSterility-Inducing Cytoplasm," Journal of Iowa Academy of Science, Vol. 95, 1988, pp. 43-46.

[23] A. G. Kishan and S. T. Borikar, "Line $\times$ Tester Analysis Involving Diverse Cytoplasmic Systems in Sorghum," Plant Breeding, Vol. 102, No. 2, 1989, pp. 153-157. doi:10.1111/j.1439-0523.1989.tb00329.x

[24] R. E. Secrist and R. E. Atkins, "Pollen Fertility and Agronomic Performance of Sorghum Hybrids with Different Male-Sterility-Inducing Cytoplasms," Journal of Iowa Academy of Science, Vol. 96, 1989, pp. 99-103.

[25] J. L. Moran and W. L. Rooney, "Effect of Cytoplasm on the Agronomic Performance of Grain Sorghum Hybrids," Crop Science, Vol. 43, No. 3, 2003, pp. 777-781. doi: $10.2135 /$ cropsci2003.0777

[26] J. F. Pedersen and J. J. Toy, "Forage Yield, Quality, and Fertility of Sorghum $\times$ Sudan Grass Hybrids in A1 and A3 Cytoplasm," Crop Science, Vol. 37, No. 6, 1997, pp. 1973-1975. doi:10.2135/cropsci1997.0011183X003700060049x
[27] J. C. Stephens and R. E. Karper, "Release of Breeding Stocks of Male Sterilized Grain Sorghum Lines," 1965.

[28] W. L. Rooney and S. Aydin, "Genetic Control of a Photoperiod-Sensitive Response in Sorghum bicolor (L.) Moench," Crop Science, Vol. 39, No. 2, 1999, pp. 397-400. doi:10.2135/cropsci1999.0011183X0039000200016x

[29] S. N. Olson, K. Ritter, W. L. Rooney, A. Kemanian, B. A. McCarl, Y. Zhang, H. Susan, D. Packer and J. Mullet, "Energy Sorghum: A Genetic Model for C4 Grass Bioenergy Crops," Biofuels, Bioproducts \& Biorefining, Vol. 6, No. 6, 2012, pp. 640-655.

[30] E. Wolfrum, C. Payne, T. Stefaniak, W. L. Rooney, N. Dighe, B. Bean and J. Dahlberg, "Multivariate Calibration Models for Sorghum Composition Using Near-Infrared Spectroscopy," Technical Report NREL/TP-510056838, 2013, pp. 1-14.

[31] D. Packer, "High-Biomass Sorghums for Biomass Fuel Production," Soil and Crop Sciences, Texas A \& M University, College Station, 2011.

[32] R. D. Lee, B. E. Johnson, K. M. Eskridge and J. F. Pedersen, "Selectin of Superior Female Parents in Sorghum Utilizing A3 Cytoplasm," Crop Science, Vol. 32, No. 4, 1992, pp. 918-921. doi:10.2135/cropsci1992.0011183X003200040016x 